\title{
Gastrointestinal Stromal Tumor Pathologic Distant Metastasis TNM Finding $v 7$
}

National Cancer Institute

\section{Source}

National Cancer Institute. Gastrointestinal Stromal T umor Pathologic Distant Metastasis

TNM Finding v7. NCI Thesaurus. Code C90056.

A pathologic finding about one or more characteristics of gastrointestinal stromal tumor, following the rules of the TNM AJCC V7 classification system as they pertain to distant metastases. There is no pathologic MO for gastrointestinal stromal tumor. (from AJCC 7th Ed.) 